\title{
Supplier Selection in J IT Automotive Industry: A Multivariate Approach
}

\author{
Isti Surjandari \\ Industrial Engineering Department, University of Indonesia \\ Kampus UI, Depok, 16424, Indonesia \\ E-mail:surjandari.2@osu.edu \\ Sumarsono Sudarto \\ Industrial Engineering Department, University of Indonesia \\ Kampus UI, Depok, 16424, Indonesia \\ E-mail:sumarsono@ie.ui.ac.id \\ Santi Anggarini \\ Industrial Engineering Department, University of Indonesia \\ Kampus UI, Depok, 16424, Indonesia \\ E-mail: anggarini90@yahoo.co.id
}

\begin{abstract}
In this globalization era, manufacturing industries have experienced many significant changes, indicated by highly-innovated and short-aged product emerging today. This condition has forced manufacturing industries to put more consideration to their core capability, thus consequently has made outsourcing activities become an important and strategic decision. A company's efforts in achieving competitive benefits begin with managing its suppliers. In real conditions, selecting suppliers is not an easy thing to decide, yet it needs a correct strategic way in order to get potential suppliers. Furthermore in Just-In-Time (JIT) manufacturer, supplier selection is an important strategic issue for the company, because it is a long-term investment and success key to the JIT philosophy implementation. The objective of this paper is to design a framework for supplier selection in JIT manufacturing based on multivariate approach. This paper is based on a study in the largest JIT automotive manufacturer in Indonesia. The design begins by applying factor analysis to settle attributes used in the supplier selection process. Afterward, a conjoint analysis is used to find out the company's preferences of its suppliers through the assessment of profiles, which are the combinations of attributes and levels used in the selection process. Selecting potential supplier can be established using Multidimensional Scaling (MDS) method. This method would specify company's preferences visually in a multidimensional space, and in the end it would set the Euclidean distance for each supplier compared to the ideal point. Eventually, this perception map would help the company in choosing suppliers which are located within their ideal point.
\end{abstract}

Keywords: : supplier selection, automotive, Just-In-Time, supply chain, multivariate analysis

\section{Introduction}

In this globalization era, manufacturing industries are in a phase of radical change. Shortness of product innovation and life cycle has forced enterprises to make reductions, keep its focus on competencies, and try to poses competitive benefits (Kannan and Tan, 2002). The growing intensity of international competition forces enterprises to reduce their vertical range of manufacture and to concentrate exclusively on their core capabilities. Certain 
enterprises reduce their suppliers in order to make their established supplier-buyer partnership more effective. Many organizations embrace partnership as a philosophy and view it as a key strategy for continued competitive success (Lettice et al., 2009).

Supplier can take part in early stage of product development, and along with the enterprise itself, this cooperation could provide varied designs with cheaper cost, more alternative solutions, and best components and technologies (Monczka et al., 1993). This context results to an increase of the proportion of purchased parts and consequently increases the dependency on suppliers. Therefore, the success of a company is determined to a greater degree by the abilities of its suppliers. Especially in automotive industry, where an automobile composed of approximately 15000 parts and outsource more than $50 \%$ of their parts (Lettice et al., 2009). The automotive industry is also a leading practitioner of Japanese-style just in time (JIT) manufacturing techniques, lean production, JIT delivery of component supplies, and minimum inventory programs. Reductions in order size and order lead time are the two purchasing elements that make JIT unique (Dong et al., 2001). Such practices make supplier selection of critical importance within the industry (Lettice et al., 2009; Reeves Jr. et al., 2010).

According to the Supply Chain Management concept, supplier selection is a beginning of a successful supply chain, one of the most fundamental and important decisions. Difficulties arise from the increased levels of complexity involved in considering various supplier performance and relationship factors. In order to perform a comprehensive sustainability evaluation of suppliers, a number of criteria may be utilized. Managers must be able to analyze and document the importance of several factors, converting instinctive and perceptual qualitative indicators to concise empirical measures (Bai and Sarkis, 2010).

Establishing the selection criteria is indeed one of the most critical parts of the supplier selection process. In addition, criteria included in the supplier selection process may frequently contradict each other, e.g. supplier with the lowest price may not have the best quality, or supplier with the best quality may not deliver on time. Therefore, a tradeoff among criteria has to be considered. The implementation of modern production strategies such as JIT and Total Quality Management (TQM) may also increase the importance of the analysis of trade-offs among the selection criteria (Karpak et al., 1999).

Difficulties in supplier selection do arise since it involves multiple criteria, which may include both qualitative and quantitative factors. One of the disadvantages of mathematical programming methods is their failure to account for qualitative factors that may affect suppliers' performance (Sawik, 2010). In order to understand trade-offs in the supplier selection process, one need to consider the relative weights that buyers attach to various characteristics of their current supplier with respect to other competitors. (Van der Rhee et al., 2009). A supplier mapping which can describe the company perception and preferences may provide a systematic way for the decision makers in making a comparison among potential suppliers.

Based on these premises, the objective of this paper is to design a framework for supplier selection in JIT manufacturing that can fulfill all evaluated demands in supplier selection (i.e., multi criteria, qualitative and quantitative consideration criteria, incorporates all decision makers' preferences, enables trade-off among criteria, and provides supplier mapping). The postulated representation and aggregation of data suggest the application of multivariate procedures, that is, by integrating factor analysis, conjoint analysis, and multidimensional scaling (MDS) in order to build the basis for the supplier selection framework.

The main contribution of this paper is in the methodological approach proposed, which enables to deal with selecting suppliers when multi criteria has to be evaluated. Multi-criteria decision making (MCDM) methods have been successfully adopted in literature to deal with supplier selection issues. However, researchers have pointed out that these methods cannot be directly applied to assess a large number of criteria, since they tend to generate inconsistencies (Botani and Rizzi, 2008). To cope with this issue, the approach developed exploits the combined application of factor analysis and conjoint analysis, which allows reducing the problem dimension by grouping criteria based on their similarities. Conjoint analysis used to assess the relative weights of each criterion based on decision makers' preferences. Past studies have shown that 
in general the market predictions generated from the statistical models based on conjoint analysis are extremely accurate (Van der Rhee et al., 2009).

The proposed method also enables to deal with a large number of suppliers, where a spatial mapping of potential suppliers based on multidimensional scaling method can provide a systematic way for the decision makers in making a comparison among potential suppliers. It is an objective procedure that analyses and represents the potential suppliers in order to rate and classify them (Lasch and Janker, 2005).

The second contribution of this paper takes place on the empirical analysis based on the case in the biggest JIT automotive manufacturer in Indonesia, with the aim of selecting the most suitable cutting tools supplier. The company has the largest market share in Indonesia and also pioneered the export of automotive parts and Completely Built$\mathrm{Up}(\mathrm{CBU})$ vehicles to various developing countries more than 200,000 units since 1997. The company currently uses components and parts from about 100 first tier suppliers.

\section{Literature Review}

Measuring certain criteria such as price, shipment, quality, and service is a common method used in selecting supplier (Ellram, 1990). However, those criteria seem to depend on the regions and types of industry and hence are very context-based. For example JIT capability may critical only in JIT companies. Reductions in order size and order lead time are the two purchasing elements that make JIT unique (Dong et al., 2001). Frequent deliveries of small lot size that facilitate inventory reduction of raw materials in JIT purchasing program make supplier equipped with Electronic Data Interchange (EDI) system into an attractive option (Boer et al., 2001). In short, the criteria used in supplier selection studies across regions and industries is differ (Lin and Purchase, 2005).

Supplier selection method has been an important research theme in the supply chain management literature. Some methods that has been used in supplier selection studies are conjoint analysis (Lin and Purchase, 2005), hierarchical regression (Power, 2008), integrated lexicographic goal programming (LGP) and analytic hierarchy process (AHP) (Cebi and Bayraktar, 2003), weighted point (Timmerman, 1986), AHP (Nydick and Hill, 1992; Gnanasekaran et al., 2006), total cost ratio (Timmerman, 1986), total cost of ownership (Ellram, 1995), principal component analysis (PCA) (Petroni and Braglia, 2000), neural network (Wei et al., 1997), total cost of ownership and AHP (Bhutta and Huq, 2002), analytic network process (ANP) (Bayazit, 2006), factor analysis and MDS (Lasch and Janker, 2005), multi-criteria decision support system (MCDSS) using AHP (Yang et al., 2008), visual interactive goal programming (Karpak et al., 1999), rating system (Thompson, 1991), optimization using linear model (Timmerman, 1986), key figures analysis (Schulte, 1996), checklist (Harting, 1994), fuzzy logic system (Urban, 1998), and conjointanalysis-like AHP (Malvinas et al., 2005). Other research shows the descriptive statistics of the studies related to supplier selection methods (Lasch and Janker, 2005).

Despite the potential benefits of the proposed methods discussed in the literature, there are still some shortcomings particularly for the case of JIT manufacturing, e.g. buyer-supplier relationships which is only based on price as the decision attribute and focus only on purchasing/procurement department and overlook other departments' preferences (Cebi and Bayraktar, 2003), AHP method can only predict the scores of attributes which are directly evaluated and it cannot take into count the interdependence that may exist among attributes (Malvinas et al., 2005), ANP requires a complex methodology with lots of comparison since it incorporates feedback and interdependent among decision attributes and alternatives (Bayazit, 2006), LGP as an optimization method requires laborious process especially with the increasing number of decision attributes, where lower priority attribute may not affect the solution because the analysis stops as soon as the procedure finds an optimal solution (Karpak et al., 1999), and no suppliers mapping which can describe the company perception and preferences (Lasch and Janker, 2005). Other research summarized the supplier selection method strengths and weaknesses (Bello, 2003).

The construction of a new method should fulfill all evaluated demands (i.e., multi criteria, qualitative and quantitative consideration criteria, incorporates all decision makers' preferences, enables trade-off 
among criteria, and provides supplier mapping). The postulated representation and aggregation of data suggest the application of multivariate procedures such as factor analysis, conjoint analysis, and multidimensional scaling in order to build the basis for the supplier selection framework.

\section{Methodology}

This research took place on a case where a supplier selection framework is needed for selecting the suppliers of cutting tools. Currently, there are nine potential suppliers for cutting tools. In order to keep establishing its mission, that is to be the leader in automotive industry, the company applies the supply chain management system. Currently, supplier selection process has been organized by the purchasing division, where the selection process is done based on four criteria, which are: price, quality, shipment, and supplier internal management. A point system is used in the supplier rating system and based on the following scale: A (90-100), B (8089), C (60-79), D (30-59), and E (0-29).

In spite of the position of purchasing division as the decision maker in the supplier selection process, other divisions also need to be involved in the process because they may have different preferences. This study uses multivariate analysis, which allows a supplier selection process that involves assessment by other relevant divisions in the company. In addition, it also takes into consideration trade-off among multiple selection criteria that involve both quantitative and qualitative, which is an important factor for successful implementation of JIT. In so doing, this study integrates multivariate techniques (i.e., factor analysis, conjoint analysis, and MDS) for selecting and evaluating suppliers.

The primary aim of factor analysis is data reduction by describing the overall of a set of correlated original variables by a smaller set of a new variables or factors without losing relevant information. The main applications of factor analysis are first to reduce the number of variables, and second to detect structures in the relationship between them (Lasch and Janker, 2004). Factor analysis enables the company to consider multiple criteria that involve both quantitative and qualitative in the supplier selection process.
Conjoint analysis is a multivariate technique used specifically to understand how respondents develop preferences for products or services (Hair et al., 2006). It is also called "CONsidered JOINTly" or "trade-off analysis". This method is based on the multi-attribute product concept, where it is assumed that individual in choosing a product or a service is based on the evaluation of all attributes simultaneously. Conjoint Analysis will deliver output in the form of quantitative measure which is utility and relative importance of an attribute compared to other attributes. It is conducted through psychological consideration or consumer's preferences. In this study, a full-profile method is used for the representation method because it gives a more explicit description of the trade-off among attributes and the existing correlation among attributes. A rating system based on likert scale is used for the preference measurement of the respondents.

Multidimensional scaling is a method for generating a two or three dimensional representation of a multidimensional space. Reminiscent of conjoint analysis, MDS is based on the respondent's ability to make judgments about the supplier. MDS is a procedure used to map the perceptions and preferences of the respondents into visually geometry map. The main purpose of MDS is to transform the respondent's opinion about the similarity or contentment of some objects into distances represented in multidimensional space.

In this study, the attribute-based MDS was used, that is, the compensatory model, where preferences obtained indirectly through the formula:

$$
S_{i}=\sum w_{i j} \times r_{i j k}
$$

where $S_{i}$ is preference for supplier $i, w_{i j}$ is importance level of atribut $j$ for supplier $i$, and $r_{i j k}$ is the value of object $k$ on atribute $j$ for supplier $i$.

For the purpose of this study, three sources were used to identify supplier selection criteria: previous literature, discussions with practitioners, and company-specific manuals. Based on these sources, 13 criteria used to select suppliers were identified, as shown in Table 1 . These reflect a variety of supplier attributes including cost, quality, delivery performance, capability, and culture.

Three sequential closed interview questionnaires are used for the data collection. In 
Table 1. Supplier Selection Criteria

\begin{tabular}{|r|l|}
\hline No. & \multicolumn{1}{|c|}{ Attributes } \\
\hline 1 & Quality \\
2 & Service \\
3 & Exact quantity of materials ordered \\
4 & On-time delivery \\
5 & Price \\
6 & Electronic Data Interchange (EDI) system usage \\
7 & Willingness to share valuable information \\
8 & Having certification or other important documents \\
9 & Ability to respond properly for unexpected demands \\
10 & Communication system owned by the supplier \\
11 & Ability to respond for emergency objects and problems \\
& immediately \\
12 & Willingness to customize products and services when there \\
13 & are changes in the needs of the company \\
& Willingness to participate in the development of new products \\
\hline
\end{tabular}

the first questionnaire, respondents were asked to provide an assessment of the attributes used in the supplier selection process (see Table 1). Respondents in this study are those who are involved in the process of assessment and selection of suppliers. They represent the division of purchasing, production, engineering, maintenance, PDA (warehouse), and quality. A likert scale is used for the first questionnaire, ranging from 1 to 5 , where 1 indicate strongly disagree factor used for supplier assessment and selection, and 5 indicate strongly agree factor used for supplier assessment and selection.

Based on factor analysis results, it can be determined the attributes and their levels. The next step is to conduct conjoint analysis by first designing stimuli which are combination of attributes and levels. On the second questionnaire, respondents were asked to provide an assessment of each stimulus using likert scale ranging from 1 to 5 , where 1 indicates that the respondent does not like a supplier with the existing combination and 5 indicates that the respondent is likely to choose a supplier with the existing combination.

The third questionnaire is intended to visually map the potential suppliers, in which respondents were asked to give their assessment of the suppliers in terms of attributes that have been determined based on conjoint analysis. A likert scale is used ranging from 1 to 5 , where 1 indicates very dissatisfied with the supplier and 5 indicates very satisfied with the supplier.
Table 2. Factor Analysis Results

\begin{tabular}{|c|c|c|}
\hline Factor & Criteria & Loading Factor \\
\hline $\begin{array}{l}\text { Communication } \\
\text { System }\end{array}$ & $\begin{array}{l}\text { - EDI system usage } \\
\text { - Willingness to share valuable } \\
\text { information } \\
\text { - Having certification or other } \\
\text { important documents } \\
\text { - Communication system owned } \\
\text { by supplier }\end{array}$ & $\begin{array}{l}0.833 \\
0.687 \\
0.643 \\
0.706\end{array}$ \\
\hline Service & $\begin{array}{l}\text { - Service } \\
\text { - Exact quantity of materials } \\
\text { ordered } \\
\text { - On-time delivery } \\
\text { - Price } \\
\text { - Willingness to customize } \\
\text { products and services when } \\
\text { there are changes in the needs } \\
\text { of the company }\end{array}$ & $\begin{array}{l}0.564 \\
0.679 \\
0.802 \\
0.610 \\
0.607\end{array}$ \\
\hline Responsiveness & $\begin{array}{l}\text { - Ability to respond properly } \\
\text { for unexpected demands } \\
\text { - Ability to respond for emergency } \\
\text { objects and problems } \\
\text { immediately }\end{array}$ & $\begin{array}{l}0.661 \\
0.836\end{array}$ \\
\hline Quality & - Quality & 0.902 \\
\hline
\end{tabular}

\section{Factor Analysis Results}

Data obtained from the first questionnaire was then analyzed using factor analysis. Factor analysis requires the Kaiser-Mayer-Olkin (KMO) value greater than 0.5 , where $\mathrm{KMO}$ measures sampling adequacy. The $13^{\text {th }}$ variable has KMO value of 0.49 , so the variable is discarded and factor analysis will be performed only by the twelve remaining

Table 3. Attributes and Levels for Conjoint Analysis

\begin{tabular}{|c|c|c|c|}
\hline \multicolumn{2}{|r|}{ Attributes } & \multicolumn{2}{|r|}{ Level } \\
\hline No. & Name & No. & Name \\
\hline 1 & Communication System & $\begin{array}{l}1 \\
2\end{array}$ & $\begin{array}{l}\text { Phone, fax, email } \\
\text { Phone, fax, email, and EDI }\end{array}$ \\
\hline 2 & Service & $\begin{array}{l}1 \\
2\end{array}$ & $\begin{array}{l}14-28 \text { days after receiving } \\
\text { PO } \\
29-42 \text { days after receiving } \\
\text { PO }\end{array}$ \\
\hline 3 & Responsiveness & $\begin{array}{l}1 \\
2\end{array}$ & $\begin{array}{l}1 \text { day, local technical support } \\
7 \text { days, foreign technical } \\
\text { support }\end{array}$ \\
\hline 4 & Quality & $\begin{array}{l}1 \\
2\end{array}$ & $\begin{array}{l}70 \%-85 \% \text { from tools life } \\
\text { time } \\
86 \%-100 \% \text { from tools life } \\
\text { time }\end{array}$ \\
\hline
\end{tabular}


variables. The number of factor is determined based on eigenvalue, since it is the commonly used method and comes from quantitative measurement, so it will produce the valid number.

Using principal component analysis with varimax rotation, the data reduction process of twelve original variables produce four new set of factors, as can be seen in Table 2.

\section{Conjoint Analysis}

The attributes for conjoint analysis is obtained from the factor analysis result. Table 3 shows attributes and levels used for conjoint analysis. The number of combination based on full factorial design with four attributes each at two levels is 16 combinations (i.e., $2 \times 2 \times 2 \times 2)$.

Communication System is the ability of suppliers in developing communication with the company. Some suppliers have implemented the Electronic Data Interchange (EDI), so that the levels for this attribute are having and not having EDI system. Services describe how suppliers can serve the needs of the company. The first level is when the supplier can provide the ordered goods within 14-28 days after receiving purchasing order (PO), and the second level is 29-42 days after receiving PO.

Responsiveness describes the response from suppliers to overcome problems that arise. Since the cutting tool components are imported products, the level used is divided into two, which are 1-day with local technical support and 7 days with foreign technical support. Quality is expressed in life time of the cutting tool and is divided into two levels, namely $70 \%-85 \%$ of the tools life time and $86 \%$ $100 \%$ of the tools life time.

Data obtained from the second questionnaire was then used for the conjoint analysis. Conjoint analysis produces importance level (range utility) and utility rate of each combination. Importance level indicates the importance of each attribute. The greater the importance level, the more important and preferable the attribute. Total importance level for all attributes is $100 \%$. A positive utility value indicates that respondent like the stimuli and vice versa.

There are six respondents who are involved in the supplier selection process and Table 4 shows the importance and utility values based on assessment of each respondent. The aggregate result is shown in Table 5 and Figure 1.

From Figure 1 it can be concluded that the respondents preferred supplier that has good quality of tool $(41.6 \%)$, can provide the ordered goods within 14-28 days (34.6\%), fast and responsive to overcome problems that arise $(11.9 \%)$, and without EDI communication system (11.9\%).

\section{Multidimensional Scaling (MDS) Results}

Data obtained from the third questionnaire was then used for the MDS, that is, to visually map the potential suppliers and its ideal point based on the preferences and perceptions of the respondents. Nine potential suppliers for cutting tools become the objects of assessment and they are coded with $\mathrm{S}_{\mathrm{i}}$ where $\mathrm{i}=1$ to 9 .

Using the compensatory method, the MDS produces two-dimensional map of the four original factors derived from factor analysis. Analysis based on two-dimensional perceptual map would be easier than that of three or even four. In compensatory model, weakness on one attribute can be covered by other attributes depending on the importance levels of the attributes. The higher the importance levels the higher its influence.

Figure 2 shows perceptual map of the potential suppliers, while Table 6 shows the Euclidean distance from each supplier to the ideal point (IP). There are three groups of suppliers resulted from the perceptual map. However, in terms of supplier selection, the supplier that will be chosen is the supplier with the smallest Euclidean distance regardless of the direction of the vector.

Group A: S1, S3, S4, S5,

This group has the closest distance to the ideal point. Suppliers in this group are distributors from wellknown product, which had very good responsiveness and service quality. To maintain the quality of their products, they always bring foreign technical support (TS) periodically. This shows their commitment to always provide the best quality. Besides providing services at the regular time, TS will also provide services at the time of unexpected problem. 
Surjandari et al: Supplier Selection in JIT Automotive Industry: A Multivariate Approach

Table 4. Importance and Utility Values of Each Respondent

\begin{tabular}{|c|c|c|c|c|}
\hline Rank & Attributes & Importance & Levels & Utility \\
\hline \multirow{4}{*}{ Respondents 1} & Communication System & 5.00 & $\begin{array}{l}\text { Phone, Fax, Email } \\
\text { Phone, Fax, Email, EDI }\end{array}$ & $\begin{array}{r}0.0625 \\
-0.0625\end{array}$ \\
\hline & Services & 45.00 & $\begin{array}{l}14-28 \text { days } \\
29-42 \text { days }\end{array}$ & $\begin{array}{r}0.5625 \\
-0.5625\end{array}$ \\
\hline & Responsivenes & 5.00 & $\begin{array}{l}\text { 1-day, local TS } \\
7 \text { days, international TS }\end{array}$ & $\begin{array}{r}0.0625 \\
-0.0625\end{array}$ \\
\hline & Quality & 45.00 & $\begin{array}{l}70-85 \% \text { of tools life time } \\
86-100 \% \text { of tools life time }\end{array}$ & $\begin{array}{r}-0.5625 \\
0.5625\end{array}$ \\
\hline \multirow{4}{*}{ Respondents 2} & Communication System & 18.75 & $\begin{array}{l}\text { Phone, Fax, Email } \\
\text { Phone, Fax, Email, EDI }\end{array}$ & $\begin{array}{r}-0.1875 \\
0.1875\end{array}$ \\
\hline & Services & 18.75 & $\begin{array}{l}14-28 \text { days } \\
29-42 \text { days }\end{array}$ & $\begin{array}{r}0.1875 \\
-0.1875\end{array}$ \\
\hline & Responsivenes & 6.25 & $\begin{array}{l}\text { 1-day, local TS } \\
7 \text { days, international TS }\end{array}$ & $\begin{array}{r}-0.0625 \\
0.0625\end{array}$ \\
\hline & Quality & 45.00 & $\begin{array}{l}70-85 \% \text { of tools life time } \\
86-100 \% \text { of tools life time }\end{array}$ & $\begin{array}{r}-0.6250 \\
0.6250\end{array}$ \\
\hline \multirow{4}{*}{ Respondents 3} & Communication System & 4.17 & $\begin{array}{l}\text { Phone, Fax, Email } \\
\text { Phone, Fax, Email, EDI }\end{array}$ & $\begin{array}{r}-0.1250 \\
0.1250\end{array}$ \\
\hline & Services & 54.17 & $\begin{array}{l}14 \text { - } 28 \text { days } \\
29 \text { - } 42 \text { days }\end{array}$ & $\begin{array}{r}0.2500 \\
-0.2500\end{array}$ \\
\hline & Responsivenes & 29.17 & $\begin{array}{l}\text { 1-day, local TS } \\
7 \text { days, international TS }\end{array}$ & $\begin{array}{r}0.2500 \\
-0.2500\end{array}$ \\
\hline & Quality & 12.50 & $\begin{array}{l}70-85 \% \text { of tools life time } \\
86-100 \% \text { of tools life time }\end{array}$ & $\begin{array}{r}-0.5625 \\
0.5625\end{array}$ \\
\hline \multirow{4}{*}{ Respondents 4} & Communication System & 4.17 & $\begin{array}{l}\text { Phone, Fax, Email } \\
\text { Phone, Fax, Email, EDI }\end{array}$ & $\begin{array}{r}-0.6250 \\
0.6250\end{array}$ \\
\hline & Services & 54.17 & $\begin{array}{l}14-28 \text { days } \\
29-42 \text { days }\end{array}$ & $\begin{array}{r}0.8125 \\
-0.8125 \\
\end{array}$ \\
\hline & Responsivenes & 29.17 & $\begin{array}{l}\text { 1-day, local TS } \\
7 \text { days, international TS }\end{array}$ & $\begin{array}{r}0.4375 \\
-0.4375\end{array}$ \\
\hline & Quality & 12.50 & $\begin{array}{l}70-85 \% \text { of tools life time } \\
86-100 \% \text { of tools life time }\end{array}$ & $\begin{array}{r}-0.1875 \\
0.1875\end{array}$ \\
\hline \multirow{4}{*}{ Respondents 5} & Communication System & 13.64 & $\begin{array}{l}\text { Phone, Fax, Email } \\
\text { Phone, Fax, Email, EDI }\end{array}$ & $\begin{array}{r}-0.1875 \\
0.1875\end{array}$ \\
\hline & Services & 22.73 & $\begin{array}{l}14-28 \text { days } \\
29-42 \text { days }\end{array}$ & $\begin{array}{r}0.3125 \\
-0.3125\end{array}$ \\
\hline & Responsivenes & 4.55 & $\begin{array}{l}\text { 1-day, local TS } \\
7 \text { days, international TS }\end{array}$ & $\begin{array}{r}0.0625 \\
-0.0625\end{array}$ \\
\hline & Quality & 59.09 & $\begin{array}{l}70-85 \% \text { of tools life time } \\
86-100 \% \text { of tools life time }\end{array}$ & $\begin{array}{r}-0.8125 \\
0.8125\end{array}$ \\
\hline \multirow{4}{*}{ Respondents 6} & Communication System & 7.69 & $\begin{array}{l}\text { Phone, Fax, Email } \\
\text { Phone, Fax, Email, EDI }\end{array}$ & $\begin{array}{r}-0.1250 \\
0.1250 \\
\end{array}$ \\
\hline & Services & 15.39 & $\begin{array}{l}14-28 \text { days } \\
29-42 \text { days }\end{array}$ & $\begin{array}{r}0.2500 \\
-0.2500\end{array}$ \\
\hline & Responsivenes & 30.77 & $\begin{array}{l}\text { 1-day, local TS } \\
7 \text { days, international TS }\end{array}$ & $\begin{array}{r}0.5000 \\
-0.5000\end{array}$ \\
\hline & Quality & 46.15 & $\begin{array}{l}70-85 \% \text { of tools life time } \\
86-100 \% \text { of tools life time }\end{array}$ & $\begin{array}{r}-0.7500 \\
0.7500\end{array}$ \\
\hline
\end{tabular}


Table 5. Aggregate Result of Conjoint Analysis

\begin{tabular}{|l|c|}
\hline \multicolumn{1}{|c|}{ Attributes } & Utility \\
\hline System Communication & Phone, fax, email \\
Service & $14-28$ days \\
Responsiveness & 1-day, local technical support \\
Quality & $86 \%-100 \%$ from tools life time \\
\hline
\end{tabular}

Figure 1. Box-Plot of Importance Values

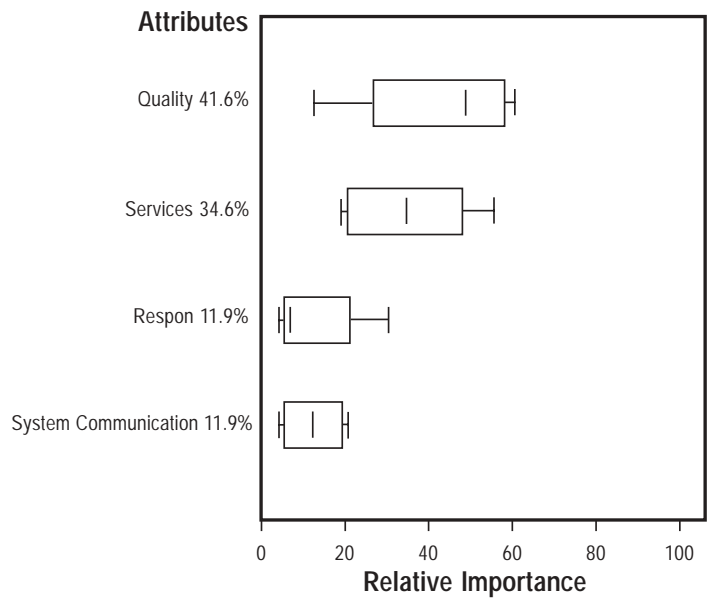

Group B: S2, S6, S7, S9

Group B is located a little farther from the ideal point which means that suppliers in this group cannot meet all the attributes desired by the company. From quality point of view, suppliers in group B have the same quality of products with that of suppliers in group A. They are cutting tools distributor of imported products with good quality. The difference lies in the response and service provided. Suppliers in group B have a marketing team that is smaller in number than that of group A. This causes the service and response given by them not as good as the suppliers in group A.

\section{Group C: S8}

There is only one supplier in this group. In contrast to the suppliers in groups A and B which are distributor of imported cutting tools, suppliers P8 is cutting tools maker, where the quality of the products cannot compete with imported product. In addition, services and responsiveness was still lower than that of group A and B.
Figure 2. Perpetual Mapping of Potential Suppliers

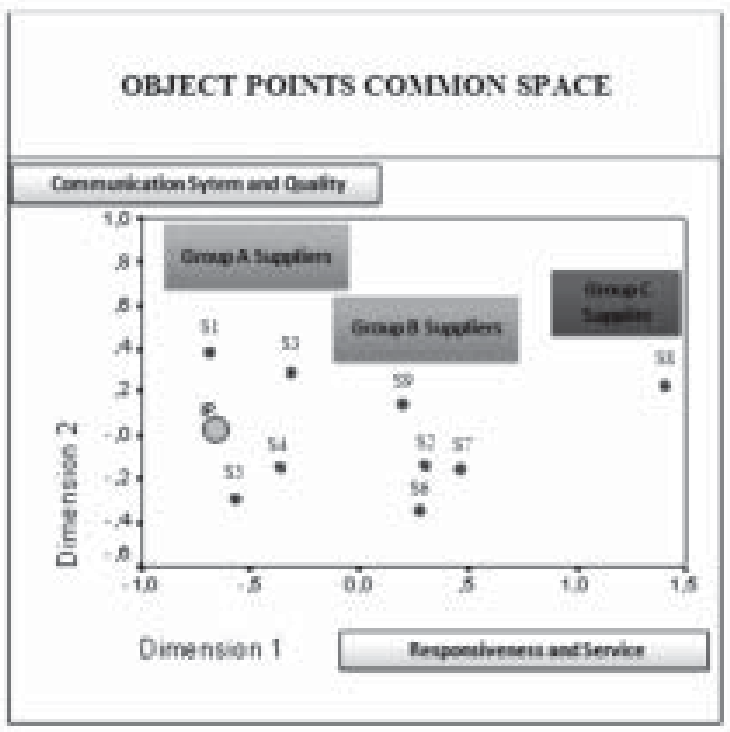

Table 6. Euclidean Distance of Each Supplier in the Perceptual Map

\begin{tabular}{|r|r|r|r|r|r|r|r|r|r|r|}
\hline & \multicolumn{1}{c|}{ S1 } & S2 & S3 & S4 & S5 & S6 & S7 & S8 & S9 & IP \\
\hline S1 &, 000 & & & & & & & & & \\
S2 & 1,116 &, 000 & & & & & & & & \\
S3 &, 385 &, 749 &, 000 & & & & & & & \\
S4 &, 617 &, 666 &, 439 &, 000 & & & & & & \\
S5 &, 683 &, 883 &, 636 &, 251 &, 000 & & & & & \\
S6 & 1,206 &, 204 &, 866 &, 673 &, 848 &, 000 & & & & \\
S7 & 1,272 &, 168 &, 898 &, 833 & 1,046 &, 268 &, 000 & & & \\
S8 & 2,099 & 1,170 & 1,721 & 1,814 & 2,047 & 1,271 & 1,019 &, 000 & & \\
S9 &, 918 &, 302 &, 534 &, 636 &, 885 &, 494 &, 401 & 1,211 &, 000 & \\
IP &, 369 & 1,004 &, 470 &, 363 &, 328 & 1,033 & 1,172 & 2,112 &, 903 &, 000 \\
\hline
\end{tabular}

\section{Conclusions}

According to the Supply Chain Management concept, supplier selection is a beginning of a successful supply chain. Enterprise's dependency on suppliers has lead manufacturing industries to make supplier management even more effective, in particular in JIT manufacturing which has high dependency on suppliers.

Supplier selection is inherently a complex decision, where establishing the selection criteria is indeed one of the most critical parts of the process and it is generally involve multiple criteria both 
quantitative and qualitative. In addition, criteria included in the supplier selection process may frequently contradict each other. Therefore, a tradeoff among criteria has to be considered. The implementation of modern production strategies such as JIT and Total Quality Management (TQM) may also increase the importance of the analysis of trade-offs among the selection criteria.

The objective of this paper is to design a framework for supplier selection in JIT manufacturing based on multivariate approach. The proposed methods integrate factor analysis, conjoint analysis and multidimensional scaling to fulfill all the demand in supplier selection process. Factor analysis produced four factors that are a simplification of the original thirteen variables used in the selection process. These four factors are communication systems, services, responsiveness, and quality. The importance level of each attributes were obtained using conjoint analysis, wherein quality $41.6 \%$, responsiveness $34.6 \%$, service $11.9 \%$, and communication system $11.9 \%$. Then the MDS is applied to represent each supplier visually on a multidimensional space, that is, by observing each supplier's smallest Euclidean distance to the point of ideal supplier. The supplier with the smallest Euclidean distance to the ideal point is the best supplier that fit to the needs and preferences of the company regardless of the direction of the vector.

The findings of this study show that factor analysis can accommodate the need for multiple selection criteria both qualitative and quantitative. While conjoint analysis allows for a trade-off among criteria. Reminiscent of conjoint analysis, MDS allows respondents to map their perceptions and assessments of the suppliers into perceptual map. Hence it allows identifying unrecognized dimensions used by respondents in making comparisons among suppliers and providing an objective basis for comparison among suppliers based on these dimensions. These findings are important because it can overcome the problems that often arise in the supplier selection process, particularly in JIT manufacturing which has high dependency on suppliers.

\section{References}

Bai, C., Sarkis, J. (2010). Integrating Sustainability into Supplier Selection with Grey System and Rough Set Methodologies. International Journal of Production Economics, 124, pp.252-264.

Bayazit, Ozden. (2006). Use of Analytic Network Process in Vendor Selection Decisions. Benchmarking: An International Journal, 13(5), pp.566-579.

Bello, M.J.S. (2003). A Case Study Approach to the Supplier Selection Process. Master Thesis, University of Puerto Rico, Mayaguez Campus.

Bhutta, K.S., Huq, F. (2002). Supplier Selection Problem: A Comparison of the Total Cost of Ownership and Analytic Hierarchy Process Approach. Supply Chain Management: An International Journa, 7(3), pp.126-135.

Bottani, E., Rizzi, A. (2008). An Adapted Multi-Criteria Approach to Suppliers and Products Selection: An Application Oriented to Lead-Time Reduction. International Journal of Production Economics, 111, pp.763-781.

Cebi, F., Bayraktar, D. (2003). An Integrated Approach for Supplier Selection. Logistics Information Management, 16(6), pp.395-400.

Dabhilkar, M., Bengtsson, L., Von Hartmaan, R., Ahlstrom, P. (2009). Supplier Selection or Collaboration? Determining Factors of Performance Improvement when Outsourcing Manufacturing. Journal of Purchasing E Supply Management, 15, pp.143-153.

De Boer, L., Labro, E., Morlacchi, P. (2001). A Review of Methods Supporting Supplier Selection. European Journal of Purchasing and Supply Management, 7, pp.7589.

Dong, Y., Carter, C.R., Dresner, M.E. (2001). JIT Purchasing and Performance: An Exploratory Analysis of Buyer and Supplier Perspectives. Journal of Operations Management, 19, pp.471-483.

Ellram, L.M. (1990). The Supplier Selection Decision in Strategic Partnerships. Journal of Purchasing and Materials Management, 26(4), pp.8-14.

Ellram, L.M. (1995). Total Cost of Ownership: An Analysis Approach for Purchasing. International Journal of Physical Distribution and Logistics Management, 25(8), pp.4-23.

Gnanasekaran, S., Vellapan, S., Manimaran. (2006). Application of Analytical Hierarchy Process in Supplier Selection: An Automobile Industry Case Study. South Asian Journal of Management, 13(4), pp.89100.

Gonzalez-Benito, J., Reis da Rocha, D., Queiruga, D. (2010). The Environment as a Determining Factor of Purchasing and Supply Strategy: An Empirical Analysis of Brazilian Firms. International Journal of Production Economics, 124, pp.1-10. 
Gosling, J., Purvis, L., Naim, M.M. (2009). Supply Chain Flexibility as a Determinant of Supplier Selection. International Journal of Production Economics, doi:10.1016/.ijpe.2009.08.029.

Hair J. F., Black, B., Babin, B., Anderson, L., Tatham, R.L. (2006). Multivariate Data Analysis, $6^{\text {th }}$ Edition, PrenticeHall International, Inc., Upper Saddle River, New Jersey.

Humpreys, P., Mclvor, R., McAleer, E. (1999). Reengineering the Purchasing Function, European Journal of Purchasing and Supply Chain, 6(2), pp.85-93.

Kannan, V. R., Tan, C. H. (2002). Supplier Selection and Assessment: Their Impact on Business Performance. Journal of Supply Chain Management, 38(4), pp.11-21.

Karpak, B., Kumcu, E., Kasuganti, R. (1999). An Application of Visual Interactive Goal Programming: A Case in Vendor Selection Decisions. Journal of MultiCriteria Decision Analysis, 8(2), pp.93-105.

Kheljani, J.G., Ghodsypour, S.H., Brien, C.O. (2009). Optimizing Whole Supply Chain Benefit versus Buyer's Benefit through Supplier Selection. International Journal of Production Economics, 121, pp.482-493.

Lasch, R., Janker, C. G. (2005). Supplier Selection and Controlling using Multivariate Analysis. International Journal of Physical Distribution \& Logistics Management, 35(6), pp.409-425.

Lettice, F., Wyatt, C., Evans, S. (2009). Buyer-Supplier Partnerships During Product Design and Development In The Global Automotive Sector: Who Invest, What and When? International Journal of Production Economics, doi:10.1016/.ijpe.2009.08.007.

Lin, Xiaoli, Purchase, S. (2005). Supplier Selection in China: A Conjoint Analysis. Proceeding of $8^{\text {th }}$ Australian and New Zealand Marketing Academy (ANZMAC) Conference, Fremantle, Western Australia, pp.49-56.

Malvinas, F., Mangkoesubroto, K., Suryadi, K., Yudhistira, T. (2005). Development of Customer Decision Model in Selecting Product Concept Based on ConjointAnalysis-Like AHP (CALAHP). Proceedings of the $8^{\text {th }}$ International Symposium on the Analytic Hierarchy Process (ISAHP), Honolulu, Hawai.

Monczka, R.M., Trent, R.J., Callahan, T.J. (1993). Supply Base Strategies to Maximize Supplier Performance. International Journal of Physical Distribution and Logistics, 23(4), pp.42-54.

Monczka, R. M., Petersen, K.J., Handfield, R.B. (1998). Success Factors in Strategic Supplier Alliances: The Buying Company Perspective. Decision Sciences, 29(3), pp.553-577.

Nassimbeni, Guido. (1995). Factors Underlying Operational JIT Purchasing Practices: Results of An Empirical Research. International Journal of Production Economics, 42, pp.275-288.
Nydick, R.L., Hill, R.P. (1992). Using AHP to Structure the Supplier Selection Procedure. International Journal of Purchasing and Material Management, 28(2), pp.3136.

Perrone, G., Roma, P., Nigro, Lo. (2010). Designing MultiAttribute Auctions for Engineering Services Procurement in New Product Development in The Automotive Context. International Journal of Production Economics, 124, pp.20-31.

Petroni, A., Braglia, M. (2000). Vendor Selection Using Principal Component Analysis. The Journal of Supply Chain Management, 36(2), pp.63-69.

Power, Damien. (2008). Capability and Practice in Procurement Collaboration: A Vendor's Perspective of Benefits. Operations and Supply Chain Management, 1(2), pp.72-84.

Reeves Jr., K.A., Caliskan, F., Oscan, O. (2010). Outsourcing Distribution and Logistics Services within the Automotive Supplier Industry. Transport Research, Part E 46, pp.459-468.

Sawik, Tadeusz. (2010). Single vs. Multiple Objectives Supplier Selection in Make To Order Environment. Omega, 39. pp.203-212.

Thompson, K.N. (1991). Scaling Evaluative Criteria and Supplier Performance Estimates in Weighted Point Prepurchase Decision Model. International Journal of Purchasing and Materials Management, 27(1), pp.27-36.

Timmerman, E. (1986). An Approach to Vendor Performance Evaluation. Journal of Purchasing and Materials Management, 22(4), pp.2-8.

Van der Rhee, Bo, Verma, R, Plaschka, G. (2009). Understanding Trade-Offs in the Supplier Selection Process: The Role of Flexibility, Delivery, and ValueAdded Service/Support. International Journal of Production Economics, 120. pp.30-41.

Velma, R., Pullman, M. E. (1998). An Analysis of the Supplier Selection Process. Omega, 26(6), pp.739-750.

Vonderembse, M. A., Tracey, M. (1999). The Impact of Supplier Selection Criteria and Supplier Involvement on Manufacturing Performance. Journal of Supply Chain Management, 35(3), pp.33-39.

Wei, S., Zhang, J., Li, Z. (1997). A Supplier-Selecting System using a Neural Network. Proceeding of IEEE International Conference on Intelligent Processing Systems, Beijing, China, pp.468-471.

Yang, A., Zahir, S., Dobing, B. (2008). A multi-Criteria Decision Support System for Selecting Cell Phone Service. The Journal of American Academy of Business, Cambrige. 14(1), pp.56-62.

Yue, J., Xia, Yu, Tran, T. (2010). Selecting Sourcing Partners for a Make-To-Order Supply Chain. Omega. 38(3-4), pp.136-144. 
Isti Surjandari is a senior lecturer in the Industrial Engineering Department, University of Indonesia. She got her bachelor degree in Industrial Engineering from University of Indonesia and Ph.D. from The Ohio State University. Her areas of interest are industrial management, quality engineering and applied statistics.

Sumarsono Sudarto is a fellow and graduate student in the Industrial Engineering Department, University of Indonesia. He got his bachelor degree in Industrial Engineering from the same University. His current research is in Operation and Supply Chain Management.

Santi Anggarini has a master degree in Industrial Engineering from University of Indonesia. She got her bachelor degree in Metallurgical Engineering, University of Indonesia. 